\title{
Finance Performance Acceleration of Company; The Impact of Change and Growth of Islamic Banks Performance in Indonesia
}

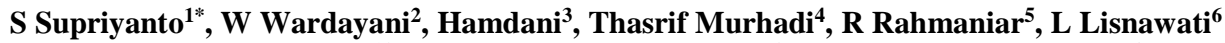 \\ \{faiziqameira@gmail.com ${ }^{1 *}$, cici_wardayani@yahoo.ac.id ${ }^{2}$, hamdani.aceh@gmail.com ${ }^{3}$, \\ thasrif.murhadi@gmail.com ${ }^{4}$, rahmaniar233@gmail.com ${ }^{5}$, lisnawati@poltekkutaraja.ac.id\} \\ ${ }^{1}$ Politeknik LP3I Medan, Medan, Indonesia \\ ${ }^{2}$ Sekolah Tinggi Ilmu Manajemen Sukma, Medan, Indonesia \\ 3,4,5,6 Politeknik Kutaraja, Banda Aceh, Indonesia
}

\begin{abstract}
. finance performance of a company is totally reflection of good management performance. As a Islamic Banks finance institution, it was claimed to have good finance performance. This study was conducted to see the finance performance acceleration of Islamic Banks. Generally, finance performance possibly achieved maximally time by time, however it is very important to re-study the acceleration and growth in certain time, yet the performance grows up simultaneously. This study was conducted in Indonesia Islamic Banks within 2009 - 2018, by secondary data which is gained from Finance Service Authority (Otoritas Jasa Keuangan) sited in www.ojk.go.id. The best performance based on score acceleration combination was achieved in 2018 which is indicated by total acceleration score of positive CAR, ROA and FDR and also negative acceleration score of NPF, however the lowest performance was in 2011 and 2017 which is indicated by the total negative acceleration score of CAR, ROA and FDR with positive NPF score acceleration.
\end{abstract}

Keywords: Finance Performance Acceleration, The Impact of Change, Growth, Islamic Banks

\section{Introduction}

An optimal performance of a company is a worth thing intended by investors on company management. Varies instruments to measure corporate finance was applied but investors tend to see the corporate finance performance. This consideration is normal due to the main reason of investors to invest is financial benefit. There are two financial benefits intended by investors, such as (1) Deviden, and (2) Capital Gain. Deviden will be gained when the ending of the statement, company gained enough benefits. However Capital Gain will be gained when the stock market prices raised or at least it has positive difference between selling price minus purchasing price if the investors sold their stock. If this condition happened, it could be assumed that the finance performance run well. Stakeholder and company management will always try to maintain the corporate financial, even every finance period, company management will always try to increase the benefits. Automatically the raising of company benefit will support corporate performance growth. Nevertheless, it is very important to study further that the growth has positive and negative trend. Islamic banking in Indonesia develops rapidly. It could be seen from the large number of Islamic banking and also its branches in almost region of Indonesia. As one of finance sub-sectors it should be examined closely. 


\section{Literature Review}

\subsection{Islamic Banking in Indonesia}

The development of banking Islamic system in Indonesia in form of dual-banking system in frame Indonesia Banking Architectures (Arsitektur Perbankan Indonesia), to present an alternative for banking service is completely helpful for Indonesian societies [1]. The characteristics of Islamic banking system which operated based on profit-sharing system contributes mutualism banking alternative systems both for the banks and also societies, it also gives justice in doing transactions, ethical investment, and prioritize the value of togetherness in production, and keeping away of speculation in transaction [1].

\subsection{Finance Performance}

Finance performance is one of analysis conducting to see how great a company has run the role of finance execution well. Company performance is the portrait of the financial condition of a company that is analyzed by financial analysis tools. Therefore it can be seen about the good and bad financial condition of a company that reflects to work performance in a certain period. This is very important to use optimally in competitive environmental changes [2]

Finance ratio was designed to see the correlation among the items in financial statement (income statement). There are 5 kinds of financial ratio;

a. Leverages ratios, show the corporate debt

b. Liquidity ratios, measure the possibility of the company to fulfill the due time liabilities

c. Efficiency or Turnover or Asset Mangement ratios, measure how effective a company manage its assets.

d. Profitabilty ratios, measure the abilities to gain profit

e. Market Value ratios, show how a company judged by investors in asset [3].

\subsection{Bank Financial Performance}

In accordance with the government constitution Number 7 of 1992 concerning Banking as amended by government constitution Number 10 of 1998, Banks are required to maintain their health. A healthy Bank is a reflection of the condition and performance of the Bank. It is a means for the supervisory authority to determine the strategy and focus of supervision of the Bank [4]. Banks are required to conduct an assessment of Bank Soundness using a risk-based Bank Rating approach, both individually and on a consolidated basis [4]. The Assessment of Bank Soundness individually by applying a risk-based Bank Rating approach (Risk-based Bank Rating), with coverage of the assessment towards these factors;

a. Risk profile

b. Good Corporate Governance (GCG)

c. Earnings

d. Capital

\subsection{Finance Performance Growth}

The mechanism of finance performance growth has 3 steps, such as:

a. First step, Growth calculation conducting growth calculation for each finance component ratio with this formula;

$$
\text { FRgrowth }-\mathrm{t}=\frac{\text { FR } \mathrm{t}-\mathrm{FR} \mathrm{t}-1}{\text { FR } \mathrm{t}-1}
$$

$\mathrm{FR}_{\text {growth-t }}$ deals with finance performance growth in certain time ( $\mathrm{t}$ period), $\mathrm{FR} \mathrm{t}_{\mathrm{t}}$ finance performance which is going to measure in definite time ( $\mathrm{t}$ period), however $\mathrm{R}_{\mathrm{t}-1}$ is finance performance which going to

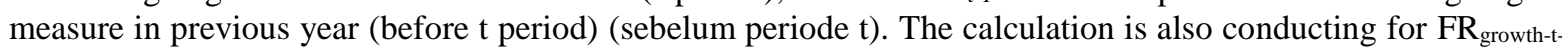
${ }_{1,}, \mathrm{FR}_{\text {growth-t-2 }}$ and so forth. 


\section{b. Second step, Growth Ratio} this

After getting the calculation for-1, so the next step is that comparing or subtracting the result by applying

$\delta_{\text {growth }}=$ FR $_{\text {growth-t }}-$ FR $_{\text {growth-t-1 }}$

formula

$\delta_{\text {growth }}=$ positive score, it means that the growth has increased or acceleration

$\delta_{\text {growth }}=0$, it means stable

$\delta_{\text {growth }}=$ negative score, it has decreased or slower

c. The third, Acceleration Interpretasion

Score $\delta_{\text {growth }}$ in every component was different even the result equals. There was differences acceleration interpretation in every instrument of finance performance (finance ratio). Not every positive score of $\delta_{\text {growth }}$ has similar meaning towards corporate finance performance, however in vice versa, there is negative $\delta_{\text {growth }}$ which has good meaning towards finance performance. To easier interpretation, the instrument to measure finance performance is grouped into 2 groups, such as:

1) $\delta_{\text {growth }}$ Positive Correlation

Financial performance measurement instrument (financial ratios) which categorized into this group if the growth is positive, can be interpreted that the corporate financial performance has increased, if the growth is negative, it means the corporate financial performance has decreased. Financial ratios are included in this group:

a) Profitabilitas Ratio such as (1) ROI, (2) ROA, (3) ROE and (4) NPM,

b) Liquidity Ratio, such as (1) Current Ratio, (2) Quick Ratio and (3) Cash Ratio,

c) Activity ration, as rotation cycle

d) Sales growth

e) Positive profit growth

2) $\delta_{\text {growth }}$ Negative correlation

The instrument of financial performance measurement (financial ratios) which is categorized into this group such as if the growth is negative, can be interpreted to the contrary, namely the corporate financial performance has increased. Financial ratios that can be included in this group such as:

a) Debt Ration, such as (1) DER, (2) Debt Ratio, etc

b) Activity Ratio such debt cycle

c) Market score ratio is PER

d) Debt growth

\section{Research method}

The object of this study is Islamic banking in Indonesia with period observation from $2009-2018$, by secondary data which was gained through finance Service Authority (Otoritas Jasa Keuangan) sited in www.ojk.go.id. The research method is descriptive analysis. It is a research to describe a phenomena, incident or recent actions. by this study, the researcher will try to describe the phenomena and incident that attract major attention without applying any treatment towards it [5]. To get the exact analysis, the researcher calculated the finance ratio through some stages. It would use finance ratio as follows;

a. Risk profile, applied Non Performing Loan (NPL) and Loan to Deposit Ratio (LDR)

1) Non Performing Loan (NPL) in Islamic banking is called Non Performing Finance (NPF). NPF include to $\delta_{\text {growth }}$ Negative Correlation

$$
\mathrm{NPF}=\frac{\text { Problematic Financing }}{\text { Total Finacing }} \times 100 \%
$$

2) Loan to Deposit Ratio (LDR), in Islamic banking is called Finance to Deposit Ratio (FDR) 


$$
\text { FDR }=\frac{\text { Total Financing }}{\text { Third Party Fund }} \times 100 \%
$$

b. Rentabilitas (earnings), was counted by rasio Return On Asset (ROA). ROA in $\delta_{\text {growth }}$ Positive correlation.

$$
\mathrm{ROA}=\frac{\text { Net Profit }}{\text { Total Asset }} \times 100 \%
$$

3. Capital was counted by Capital Adequacy Ratio (CAR)

$$
\mathrm{CAR}=\frac{\text { Bank asset }}{\mathrm{ATMR}} \times 100 \%
$$

After calculating the ration of finance performance, further calculation was conducted, such finance growth performance calculation through 3 stages :

1. Growth calculation

2. Growth ratios

3. Acceleration Interpretation

\section{Result and discussion}

Based on the data gained through Finance Service Authority (Otoritas Jasa Keuangan) sited in www.ojk.go.id and after analyzed each ratio, to get the data in calculating stage-3 (work interpretation in 10 years), yet in the first calculation, it needs 12 years observation data $(n+2)$. The result of the calculation can be seen as Table 1 below.

Table 1. Finance Ratio in 2007 - 2018

\begin{tabular}{l|rrrrrrrrrrrr}
\hline Ratios & \multicolumn{10}{|c}{ Years } \\
\cline { 2 - 12 } & 2007 & 2008 & 2009 & 2010 & 2011 & 2012 & 2013 & 2014 & 2015 & 2016 & 2017 & 2018 \\
\hline CAR (\%) & 10,67 & 12,81 & 10,77 & 16,25 & 16,63 & 14,13 & 14,42 & 15,74 & 15,02 & 16,63 & 17,91 & 20,39 \\
ROA (\%) & 2,07 & 1,42 & 1,48 & 1,67 & 1,79 & 2,14 & 2,00 & 0,41 & 0,49 & 0,63 & 0,63 & 1,28 \\
NPF (\%) & 4,05 & 1,42 & 4,01 & 3,02 & 2,52 & 2,22 & 2,62 & 4,95 & 4,84 & 4,42 & 4,76 & 3,26 \\
FDR (\%) & 99,76 & 103,65 & 89,70 & 89,67 & 88,94 & 100,00 & 100,3 & 86,66 & 88,03 & 85,99 & 79,61 & 78,53 \\
\hline & \multicolumn{10}{c}{2} \\
\hline
\end{tabular}

Source : Financial Service Authority, 2019, managed

Information :

$\mathrm{CAR}(\%) \quad=$ Capital Adequacy Ratio, as a percentage

ROA $(\%) \quad=$ Return On Asset, as a percentage

$\mathrm{NPF}(\%) \quad=$ Non Performing Finance, as a percentage

FDR $(\%) \quad=$ Finance to Deposit Ratio, as a percentage

Regarding to the data in Table 1, so the next step is calculating the finance performance growth, (step-1), by CAR 2008 calculation as follows:

FRgrowth $-\mathrm{t}=\frac{\text { FR } \mathrm{t}-\mathrm{FR} \mathrm{t}-1}{\mathrm{FR} \mathrm{t}-1}$

CAR $-2008=\frac{12,81-10,67}{10,67}$

$\mathrm{CAR}_{2008}=0,20$

The calculation for all ratio components was applied through calculation CAR 2008 , and the result can be seen in Table 2. 
Table 2. Finance Ratio Growth in $2008-2018$

\begin{tabular}{c|ccccccccccc}
\hline Ratios & \multicolumn{10}{|c}{ Years } \\
\cline { 2 - 13 } & 2008 & 2009 & 2010 & 2011 & 2012 & 2013 & 2014 & 2015 & 2016 & 2017 & 2018 \\
\hline CAR & 0,20 & $-0,16$ & 0,51 & 0,02 & $-0,15$ & 0,02 & 0,09 & $-0,05$ & 0,11 & 0,08 & 0,14 \\
ROA & $-0,31$ & 0,04 & 0,13 & 0,07 & 0,20 & $-0,07$ & $-0,79$ & 0,17 & 0,30 & 0,00 & 1,01 \\
NPF & $-0,65$ & 1,82 & $-0,25$ & $-0,17$ & $-0,12$ & 0,18 & 0,89 & $-0,02$ & $-0,09$ & 0,08 & $-0,31$ \\
FDR & 0,04 & $-0,13$ & 0,00 & $-0,01$ & 0,12 & 0,00 & $-0,14$ & 0,02 & $-0,02$ & $-0,07$ & $-0,01$ \\
\hline
\end{tabular}

Source : Financial Service Authority, 2019, managed

Information: :

$\begin{array}{ll}\text { CAR } & =\text { the growth of Capital Adequacy Ratio } \\ \text { ROA } & =\text { the growth of Return On Asset } \\ \text { NPF } & =\text { the growth of Non Performing Finance } \\ \text { FDR } & =\text { the growth of Finance to Deposit Ratio }\end{array}$

After getting the calculation of finance performance growth, next it would be compared (step-2), by sample calculation CAR 2008 as follows:

$\delta_{\text {growth }}=$ FR growth-t - FR growth-t-1

$\delta_{\text {growth }}=$ the growth of CAR $2009-$ the growth of CAR 2008

$\delta_{\text {CAR -2009 }}=-0,16-0,20$

$\delta_{\mathrm{CAR}-2009}=-0,36$

The calculation for all growth ratios was conducted as calculation $\delta_{\text {CAR-2009, }}$, so the result of finance performance acceleration of Islamic Banking in $2009-2018$ (10 years observation) can be seen in Table 3 .

Table 3. Calculation of Finance Performance Acceleration

\begin{tabular}{|c|c|c|c|c|c|c|c|c|c|c|c|}
\hline \multirow{2}{*}{ Ratios } & \multicolumn{11}{|c|}{ Years } \\
\hline & 2009 & 2010 & 2011 & 2012 & 2013 & 2014 & 2015 & 2016 & 2017 & 2018 & Averages \\
\hline CAR $(\delta)$ & $-0,36$ & 0,67 & $-0,49$ & $-0,17$ & 0,17 & 0,07 & $-0,14$ & 0,15 & $-0,03$ & 0,06 & $-0,01$ \\
\hline $\operatorname{ROA}(\delta)$ & 0,36 & 0,09 & $-0,06$ & 0,12 & $-0,26$ & $-0,73$ & 0,96 & 0,13 & $-0,30$ & 1,01 & 0,13 \\
\hline $\operatorname{NPF}(\delta)$ & 2,47 & $-2,07$ & 0,08 & 0,05 & 0,30 & 0,71 & $-0,91$ & $-0,07$ & 0,16 & $-0,39$ & 0,03 \\
\hline $\operatorname{FDR}(\delta)$ & $-0,17$ & 0,13 & $-0,01$ & 0,13 & $-0,12$ & $-0,14$ & 0,15 & $-0,04$ & $-0,05$ & 0,06 & $-0,01$ \\
\hline
\end{tabular}

Source : Financial Service Authority, 2019, managed

Information :

$\operatorname{CAR}(\delta)=$ Acceleration of Capital Adequacy Ratio

$\operatorname{ROA}(\delta)=$ Acceleration of Return On Asset

$\operatorname{NPF}(\delta) \quad=$ Acceleration of Non Performing Finance

FDR $(\delta)=$ Acceleration of Finance to Deposit Ratio

The calculation in Table 3 was gained score $\delta_{\text {growth }}$ in every component that stated the acceleration score of every ratio component every year. CAR, ROA, and FDR was the finance ratio group of positive correlation (especially for FDR, there will be limit), however NPF included in finance ratio group of negative correlation. Table 3 contributes some information based on the calculation of each finance ratio component.

1. Acceleration Interpretation of Capital Adequacy Ratio (CAR)

Akselerasi Capital Adequacy Ratio (CAR) was categorized in $\delta_{\text {growth }}$ positive correlation. The acceleration score of Capital Adequacy Ratio (CAR) within 2009 - 2018 fluctuated average - 0,01. The best acceleration was achieved in 2010, with the score 0,67 , however in 2011 has the lowest acceleration with the score $-0,49$. 2. Acceleration interpretation of Return On Asset (ROA)

Return On Asset (ROA) Acceleration was categorized in $\delta_{\text {growth }}$ positive correlation. The acceleration score of Return On Asset (ROA) in the last 10 years was in 2009 to 2018 has cash flows with the average score 0,13 , 
it means that the performance of Islamic banking was totally good enough,. It was indicated by the acceleration score of ROA dominantly positive. The best acceleration was achieved in 2015, with the score of 0,97, despite in 2014 has lowest acceleration score, that's $-0,73$.

3. Acceleration interpretation of Non Performing Finance (NPF)

Return On Asset (ROA) Acceleration was categorized in $\delta_{\text {growth }}$ negative correlation. Acceleration score of Non Performing Finance (NPF) within 2009 - 2018 fluctuated with the average score 0,03 it means that the average score of NPF or problematic financing raised up, furthermore, it needs more efforts to press the positive growth of NPF. The best NPF acceleration was achieved in 2010, with the score $-2,07$, although in 2014 NPF has lowest acceleration score, that's 2,47

4. Acceleration interpretation of Finance to Deposit Ratio (FDR)

Finance to Deposit Ratio (FDR) Acceleration was categorized in $\delta_{\text {growth }}$ positive correlation, even with limit. FDR acceleration score within $2009-2018$ fluctuated with the average score - 0,01 it means that the FDR acceleration has slower growth, therefore it needs more effort from Islamic banking to change the average score into positive. The best FDR acceleration was achieved in 2015, the score was 0,15, with the lowest acceleration score $-0,14$ in 2014.

Eventually, the best performance of Islamic Banking based on CAR, ROA, NPF and FDR was achieved in 2018. It was indicated from the acceleration score combination of CAR, ROA, NPF and FDR which worked as intention. CAR, ROA and FDR has positive acceleration score and NPF has negative acceleration score.

\section{Conclusion}

The impact of Capital Adequacy Ratio (CAR), Return On Asset (ROA), Non Performing Finance (NPF) and Finance to Deposit Ratio (FDR) change and growth caused performance acceleration of Islamic Banking fluctuated in the recent 10 years, start from 2009 to 2018. The best performance based on acceleration score combination was achieved in 2018 which was indicated by the acceleration score of positive CAR, ROA and FDR and also negative NPF score however the lowest performance was in 2011 and 2017 which was indicated by negative CAR, ROA and FDR acceleration, and also positive acceleration score of NPF.

\section{References}

[1] www.ojk.go.id

[2] Fahmi, I. (2012). Pengantar manajemen keuangan. Bandung: Alfabeta.

[3] Atmaja, L. S. (2008). Teori dan praktik manajemen keuangan. Yogyakarta: Andi.

[4] Peraturan Otoritas Jasa Keuangan Nomor 4 /POJK.03/2016 Tentang Penilaian Tingkat Kesehatan Bank Umum

[5] Juliansyah Noor, S. E. (2016). Metodologi Penelitian: Skripsi, Tesis, Disertasi \& Karya Ilmiah. Prenada Media. 